\title{
Kemampuan Multirepresentasi Siswa dalam Pembelajaran aPBL (Authentic Problem Based Learning) Pada Materi Elastisitas Dan Getaran
}

\author{
Ratika Sekar Ajeng A. ${ }^{1}$, Arif Hidayat $^{2}$, Lia Yuliati ${ }^{2}$ \\ ${ }^{1)}$ Prodi Fisika, Universitas NahdlatulUlamaBlitar \\ ${ }^{2)}$ Jurusan Fisika, Universitas Negeri Malang \\ ratikasekar@gmail.com
}

\section{Tersedia Online di}

http://www.jurnal.unublitar.ac.id/

index.php/briliant

\begin{tabular}{l}
\hline Sejarah Artikel \\
\hline Diterima pada 30 Januari 2019 \\
Disetuji pada 20 Februari 2019 \\
Dipublikasikan pada 20 Februari \\
2019 Hal. 97-104 \\
\hline
\end{tabular}

\section{Kata Kunci:}

Pembelajaran aPBL, Kemampuan

Multirepresentasi

\section{DOI:}

http://dx.doi.org/10.28926/briliant .v3i3.273

\begin{abstract}
Abstrak: Penelitian ini merupakan penelitian kualitatif tipe fenomenologi yang bertujuan mendeskripsikan perkembangan kemampuan multirepresentasi siswa dalam pembelajaran aPBL. Subjek penelitian adalah siswa kelas XI SMA. Data penelitian dianalisis secara secara kualitatif dengan mendeskripsikan temuan secara tekstual, grafik, dantabel. Hasil analisis data menunjukkan bahwa kemampuan multirepresentasi siswa yang menonjol adalah kemampuan multirepresentasi matematis dan yang kurang adalah kemampuan multirepresentasi verbal. Dari kuesioner respon siswa, siswa paling menyukai format soal bergambar dan menyelesaikan permasalahan dengan mengilustrasikan jawaban.
\end{abstract}

\section{PENDAHULUAN}

Salah satu tujuan utama pembelajaran fisika adalah menghasilkan pemecah masalah yang dapat mentransfer pengetahuan dan pemahamannya pada situasi dunia nyata. Banyak penelitian pendidikan yang meneliti kesulitan konseptual yang dialami siswa, tetapi masih sedikit penelitian yang fokus pada pembentukan kemampuan siswa untuk menyelesaikan masalah secara kuantitatif (Heron, P dan Meltzer, D., 2005). Kelemahan kerangka konsep siswa bisa menjadi halangan yang besar dalam pemecahan masalah (Hegde, B. dan Meera, B. N., 2012).

Banyak penelitian menunjukkan bahwa walaupun siswa dapat belajar menyelesaikan masalah kuantitatif dengan memasukkan nilai pada persamaan algoritma, siswa mungkin tidak membangun keterampilan yang dibutuhkan untuk mentransfer pemahaman dan menyelesaikan permasalahan yang lebih kompleks (Kim, E dan S. J. Pak, S. J., 2001; Mazur, E., 1992; Mazur, E., 1997; Redish, E., 2005). Sehingga pembelajaran seharusnya membuat siswa berpikir sebagai fisikawan atau menghasilkan pergeseran dari awam pemecah masalah menjadi ahli pemecah masalah.

Salah satu aspek kemampuan pemecahan masalah yang mendapat banyak perhatian dalam komunitas pendidikan fisika adalah isu tentang representasi. 
Dengan menggeneralisasi dan menggunakan representasi eksternal, siswa membangun kemampuan kognitif siswa dalam situasi tertentu untuk menyelesaikan masalah (Ibrahim, B. dan Rebello, S. N., 2012). Selanjutnya, kemampuan untuk menyampaikan informasi dalam berbagai model representasi adalah kemampuan yang perlu dibangun siswa(Kohl, P. B. dan Finkelstein, N. D., 2008).

Siswa kurang ahli menggunakan pendekatan pemecahan masalah secara kualitatif ketika menyelesaikan permasalahan fisika dengan berbagai representasi. Van Heuvelen (1991) menyarankan bahwa pendekatan pemecahan masalah secara kualitatif yang baik adalah dengan menganalisis situasi dan membuat diagram atau grafik yang merepresentasikan permasalahan.Penelitian-penelitian sebelumnya mengasumsikan bahwa kemampuan multirepresentasi memiliki peran penting dalam perolehan konsep siswa dalam pembelajaran fisika. Ilmuwan ahli mampu menggunakan multirepresentasi ketika berpikir dan menyatakan ide secara lancar (Kohl, P. B. dan Finkelstein, N. D.,2008; Kozma, R. B. dan Russell, J., 1997), dan ini merupakan salah satu tujuan penting dalam pendidikan fisika untuk membimbing siswa seperti siswa ahli dalam menggunakan multirepresentasi untuk proses penyelesaian masalah dan pemahaman konsep fisika (Heuvelen A. V. dan Zou, X., 2001).

Penyajian permasalahan-permasalahan pada materi elastisitas dan getaran menggunakan banyak representasi. Untuk menyelesaikan permasalahan dengan berbagai representasi, dibutuhkan kemampuan multirepresentasi yang baik.

Dalam mengembangkan kemampuan multirepresentasi diperlukan pembelajaran yang sesuai. Pembelajaran aPBL(authentic Problem Based Learning) merupakan pembelajaran yang menantang, memotivasi, metode pembelajaran berpusat pada siswa yang menstimulasi siswa untuk memperoleh dan mengaplikasikan pengetahuan dan keterampilan yang dibutuhkan termasuk pemecahan masalah, pembelajaran yang mengarah pada diri sendiri, keterampilan berkelompok, dan bertanggungjawab terhadap pembelajarannya sendiri (Barrows, H. S. dan Neo, W. K., 2007).

Tujuan pembelajaran aPBL adalah mencetak siswa yang memiliki kemampuan-kemampuan yang diperlukan di dunia kerja. Siswa yang memperoleh aPBL adalah siswa yang dapat menunjukkan kemampuan pemecahan, pembaharuan diri, dan kerjasama yang lebih baik karena telah belajar dalam konteks yang sesuai dengan dunia kerja dengan ambiguitas dan ketidakpastian. Siswa juga merupakan orang yang termotivasi dan terlibat karena mampu bekerja dalam masalah otentik yang diberikan dalam pembelajaran (Barrows, H. S. dan Neo, W. K., 2007). Tujuan penelitian ini adalah untuk mendeskripsikan perkembangan kemampuan multirepresentasi siswa dalam pembelajaran aPBL.

\section{METODE PENELITIAN}

Penelitian yang dilakukan menggunakan pendekatan kualitatif tipe fenomenologi. Penelitian ini dilaksanakan di SMA Negeri 4 kota Blitar dengan subjek penelitian siswa kelas XI IPA 3. Data penelitian ini adalah data kemampuan multirepresentasidan data respon siswa terhadap pembelajaran. Instrumen penelitian yang digunakan adalah lembar observasi, LKS, lembar tes kemampuan multirepresentasi, dan kuesioner respon pembelajaran. Data dianalisis secara kualitatifdenganmendeskripsikantemuansecaratekstual, grafik, dantabel. 
Langkah-langkah pengumpulan data dalam penelitian ini adalah sebagai berikut (1) siswa diberi perlakuan yaitu dengan pembelajaran aPBL, (2) selama pembelajaran siswa diberi kuis dengan bentuk soal multirepresentasi untuk memantau perkembangan kemampuan multirepresentasi siswa, (3) Setelah perlakuan diberikan, siswa diberi kuesioner untuk mengetahui respon siswa terhadap pembelajaran aPBL yang mengembangankan kemampuan multirepresentasi siswa.

\section{HASIL PENELITIAN DAN PEMBAHASAN \\ Deskripsi Perkembangan Kemampuan Multirepresentasi}

Perkembangan kemampuan multirepresentasi siswa dalam pembelajaran aPBL pada materi elastisitas dan getaran dianalisis dari jawaban siswa pada soal kuis.

Dari analisis kuis untuk kemampuan multirepresentasi, didapatkan bahwa kemampuan siswa yang paling menonjol adalah kemampuan multirepresentasi matematis, sedangkan kemampuan multirepresentaasi yang kurang adalah kemampuan multirepresentasi verbal. Hal ini tampak pada Gambar 1 yang menunjukkan perbandingan jumlah siswa yang mampu mengerjakan soal kuis dengan berbagai multirepresentasi.

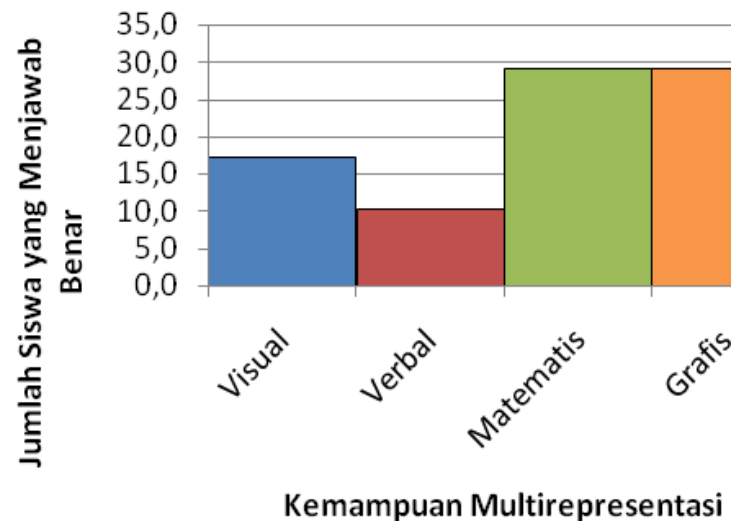

Gambar 1. Diagram jumlah siswa yang menjawab benar pada masing-masing kemampuan multirepresentasi

Dari analisis jawaban soal kuis kemampuan multirepresentasi, siswa sangat lancar mengerjakan soal secara matematis karena sudah terbiasa, terutama dalam menghitung atau mengaplikasikan persamaan dalam soal. Dalam menganalisis persamaan getaran, siswa masih perlu bimbingan guru. Salah satu contoh jawaban siswa dengan format matematis ditunjukkan pada Gambar 2. 


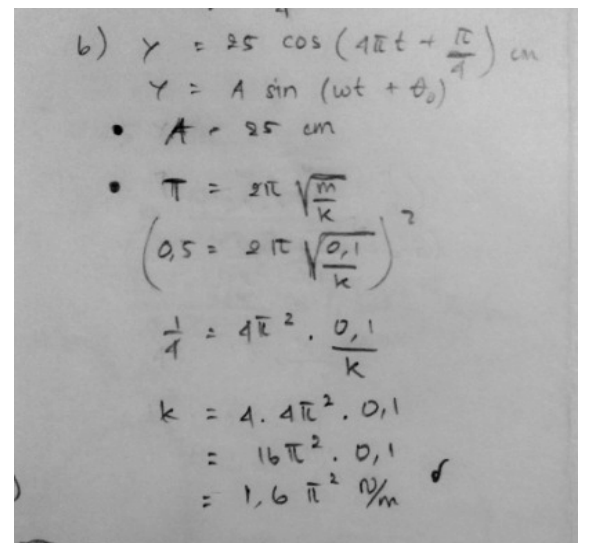

Gambar 2. Salah satu jawaban siswa yang mengerjakan soal kuis secara matematis dengan menganalisis persamaan getaran

Ketika siswa diminta untuk menjelaskan konsep yang berlaku pada permasalahan fisika, siswa merasa kesulitan, bahkan banyak siswa yang tidak menjawab. Kebanyakan siswa hanya mengetahui rumus yang berlaku tanpa memahami konsep. Salah satu contoh jawaban siswa dengan format verbal ditunjukkan pada Gambar 3.

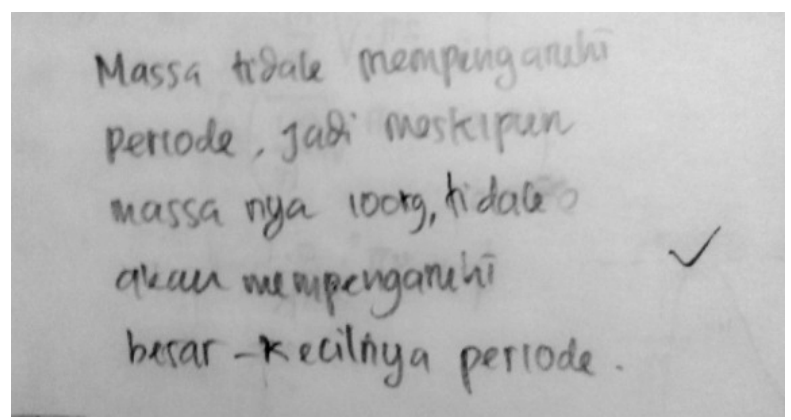

Gambar 3. Salah satu jawaban siswa yang mengerjakan soal kuis secara verbal dengan menganalisis periode gerak bandul sederhana

Untuk kemampuan multirepresentasi visual, sebagian siswa bisa menyelesaikan permasalahan dengan format tersebut, sebagian siswa yang lain masih bingung menganalisis gambar atau mengilustrasikan gambar yang sesuai dengan permasalahan. Guru telah melatih siswa mengilustrasikan permasalahan dalam bentuk gambar agar permasalahan mudah dimengerti dan dicari solusinya, namun sebagian siswa justru semakin kebingungan ketika menggunakan cara tersebut, terutama pada materi getaran. Salah satu contoh jawaban siswa dengan format visual ditunjukkan pada Gambar 4. 


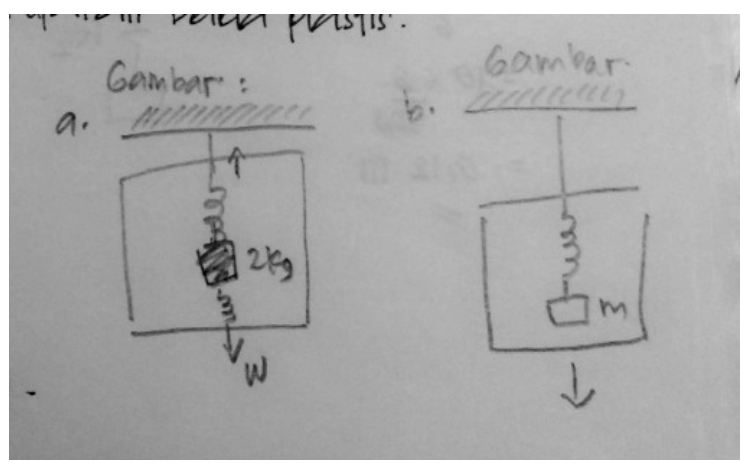

Gambar 4. Salah satu jawaban siswa yang mengerjakan soal kuis secara visual dengan menganalisis gerak pegas dalam lift yang bergerak

Untuk kemampuan multirepresentasi grafis, siswa lancar dalam menganalisis dan membuat grafik hubungan gaya pegas dengan pertambahan panjang pegas. Sedangkan untuk materi getaran siswa sedikit kesulitan membuat atau menganalisis grafik sehingga masih perlu dibimbing guru. Salah satu contoh jawaban siswa pada soal kuis dengan format grafis ditunjukkan pada Gambar 5.

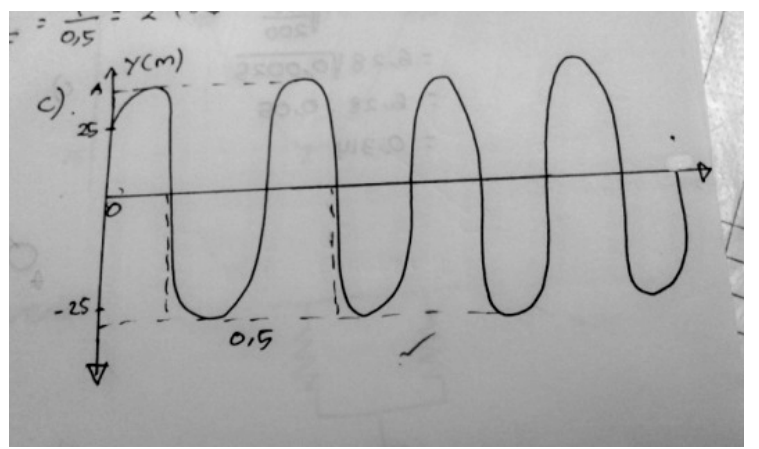

Gambar 5. Salah satu jawaban siswa yang mengerjakan soal kuis secara grafis dengan membuat grafik getaran pegas

\section{Respon terhadap pembelajaran aPBL}

Hasil analisis kuesioner respon siswa terhadap pembelajaran aPBL yang mengembangkan kemampuan multirepresentasi, diperoleh data respon siswa terhadap soal dengan format berbagai multirepresentasi yang ditampilkan pada Tabel 1.

Tabel 1. Tabel respon siswa terhadap soal dengan format berbagai multirepresentasi

\begin{tabular}{llllll}
\hline $\begin{array}{l}\text { Format } \\
\text { Soal }\end{array}$ & $\begin{array}{l}\text { Suka } \\
(\%)\end{array}$ & $\begin{array}{l}\text { Tidak } \\
(\%)\end{array}$ & Suka & $\begin{array}{l}\text { Mudah } \\
(\%)\end{array}$ & $\begin{array}{l}\text { Sulit } \\
(\%)\end{array}$ \\
\hline Cerita & 19.35 & 35.48 & 19.35 & 19.35 \\
\hline $\begin{array}{l}\text { Bergamba } \\
\mathrm{r}\end{array}$ & 45.16 & 12.90 & 48.39 & 16.13 \\
\hline $\begin{array}{l}\text { Persamaa } \\
\mathrm{n}\end{array}$ & 32.26 & 19.35 & 19.35 & 35.48 \\
\hline Grafik & 3.23 & 32.26 & 12.90 & 29.03 \\
\hline
\end{tabular}


Untuk pilihan cara menyelesaikan permasalahan fisika yang dipilih siswa ditunjukkan pada Tabel 2.

Tabel 2. Tabel cara menyelesaikan permasalahan fisika yang dipilih siswa

\begin{tabular}{lll}
\hline $\begin{array}{l}\text { Cara Menyelesaikan } \\
\text { Masalah }\end{array}$ & $\begin{array}{l}\text { Jumlah } \\
\text { yang } \\
(\%)\end{array}$ & $\begin{array}{r}\text { Siswa } \\
\text { memilih }\end{array}$ \\
\hline Menjelaskan konsep & 25.81 & \\
\hline $\begin{array}{l}\text { Mengilustrasikan jawaban } \\
\text { dalam bentuk gambar }\end{array}$ & 54.84 & \\
\hline $\begin{array}{l}\text { Menggunakan persamaan } \\
\text { matematis }\end{array}$ & 16.13 & \\
\hline Membuat grafik & 3.23 & \\
\hline
\end{tabular}

Dalam menyelesaikan permasalahan fisika, dibutuhkan kemampuan multirepresentasi yang baik, namun dari hasil penelitian tidak semua kemampuan multirepresentasi dikuasai dengan baik oleh siswa. Data menunjukkan bahwa kemampuan multirepresentasi yang kurang adalah kemampuan multirepresentasi verbal, namun untuk kemampuan multirepresentasi visual dan grafis siswa sudah baik. Hal ini sesuai dengan saran Van Heuvelen (1991) yang menyatakan bahwa pendekatan pemecahan masalah secara kualitatif yang baik adalah dengan menganalisis situasi dan membuat diagram atau grafik yang merepresentasikan permasalahan.

Dari analisis kuesioner respon siswa terhadap pembelajaran aPBL, ternyata format soal yang paling disukai adalah format soal bergambar dengan mayoritas memberi alasan siswa lebih paham permasalahan, namun hal ini tidak sesuai dengan hasil analisis jawaban soal kuis siswa yang menunjukkan kemampuan multirepresentasi visual kurang begitu baik, walaupun siswa juga paling banyak mengilustrasikan permasalahan dalam bentuk gambar. Sedangkan kemampuan multirepresentasi yang paling baik adalah kemampuan multirepresentasi matematis. Menurut Mazur, dkk walaupun siswa dapat belajar menyelesaikan masalah kuantitatif dengan memasukkan nilai pada persamaan algoritma, siswa mungkin tidak membangun keterampilan yang dibutuhkan untuk mentransfer pemahaman dan menyelesaikan permasalahan yang lebih kompleks (Kim, E dan S. J. Pak, S. J., 2001; Mazur, E., 1992; Mazur, E., 1997; Redish, E., 2005).

\section{KESIMPULAN}

Kesimpulan dari penelitian ini adalah pembelajaran aPBL membantu siswa dalam mengembangkan kemampuan multirepresentasi. Kemampuan multirepresentasi siswa dalam pembelajaran aPBL berkembang dengan cukup baik. Kemampuan multirepresentasi siswa yang paling menonjol adalah kemampuan multirepresentasi matematis walaupun dari respon siswa, siswa cenderung menyelesaikan permasaalahana fisika secara visual. 


\section{SARAN}

Kemampuan siswa memiliki multireprentasi dapat membantu dalam menyelesaikan permasalahan fisika.Sehingga disarankan dilakukan penelitian lanjutan untuk menguji dan mendeskripsikan hubungan antara kemampuan multirepresentasi dan pemecahan masalah (problem solving skill).

\section{UCAPAN TERIMAKASIH}

Penulis terimakasih kepada bapak ibu dosen pembimbing yaitu Prof. Dr. Arif Hidayat, M.Si dan Dr. Lia Yuliati, M.Pd yang banyak memberi masukan dan saran atas pelaksanaan penelitian dan penulisan laporan hasil penelitian, kepada validator instrumen penelitian, dan kepada kepala sekolah beserta guru kelas SMAN 4 Blitar yang memberikan ijin melakukan penelitian.

\section{DAFTAR RUJUKAN}

Barrows, H. S. dan Neo, W. K.. 2007. Principle and Practice of aPBL. Singapura: Pearson Education South Asia Pte Ltd.

Hake, R.R. 2007. Design-Based Research in Physics Education Research: A Review. A.E. Kelly, R.A. Lesh, \& J.Y. Baek, eds. (in press). Handbook of Design Research Methods in Mathematics, Science, and Technology Education. Erlbaum: (online) (http://www.physics.indiana.edu), diakses 7 April 2013.

Hegde, B. dan Meera, B. N.. 2012. How do they solve it? An insight into the learner's approach to the mechanism of physics problem solving. Phys. Rev. ST Phys. Educ. Res., (Online)8, 010109, (http://prst-per.aps.org), diakses 18 Maret 2013.

Heron, P dan Meltzer, D. 2005. Guest Editorial, The future of physics education research: Intellectual challenges and practical concerns. Am. J. Phys., (Online), 73, 390, (http://ajp.aapt.org), diakses 7 April 2013.

Heuvelen A. V. dan Zou, X. 2001. Multiple representations of work energy processes. Am. J. Phys., (Online), 69, 184, (http://ajp.aapt.org), diakses 7 April 2013.

Ibrahim, B. dan Rebello, S. N.. 2012. Representasional Task Formats and Problem Solving Strategies in Kinematics and Work. Phys. Rev. ST Phys. Educ. Res., (Online)8, 010126, (http://prst-per.aps.org), diakses 2 Februari 2013.

Kim, E dan S. J. Pak, S. J. 2001. Students do not overcome conceptual difficulties after solving 1000 traditional problems. Am. J. Phys., (Online), 70, 759, (http://ajp.aapt.org), diakses 7 April 2013.

Kohl, P. B. dan Finkelstein, N. D. 2008. Patterns of multiple representation use by experts and novices during physics problem solving. Phys. Rev. ST Phys. Educ. Res., (Online), 4, 010111, (http://prst-per.aps.org), diakses 18 Maret 2013.

Kozma, R. B. dan Russell, J. 1997. Multimedia and Understanding: Expert and Novice Responses to Different Representations of Chemical Phenomena. J. Res. Sci. Teach., (Online), 34, 949, (http://narst.org/publications/jrst.cfm), diakses 6 April 2013.

Mazur, E. 1992. Qualitative vs. quantitative thinking: Are we teaching the right thing?. Opt.Photonics News, (Online), 3,38, (http://www.osa-opn.org), diakses 7 April 2013. 
Mazur, E. 1997. Peer instruction-A user's manual. New Jersey: Prentice-Hall, Englewood Cliffs.

Redish, E. 2005. Changing student ways of knowing: What should our students learn in a physics class? In Proceedings of World View on Physics Education 2005: Focusing on Change, New Delhi. Singapura: World Scientific Publishing Co, (Online), (http://www.physics.umd.edu/perg/papers/redish/IndiaPlen.pdf), diakses 21 Maret 2013.

Van H. A. 1991. Learning to think like a physicist: A review of research-based instructional strategies. Am. J. Phys., (Online) 59, 891, (http://ajp.aapt.org), diakses 7 April 2013. 